\title{
Biosynthesis of the carbohydrate moieties of arabinogalactan proteins by membrane-bound $\beta$-glucuronosyltransferases from radish primary roots
}

\author{
Maya Endo · Toshihisa Kotake • Yoko Watanabe • \\ Kazumasa Kimura $\cdot$ Yoichi Tsumuraya
}

Received: 24 June 2013 / Accepted: 9 September 2013 / Published online: 22 September 2013

(C) The Author(s) 2013. This article is published with open access at Springerlink.com

\begin{abstract}
A membrane fraction from etiolated 6-day-old primary radish roots (Raphanus sativus L. var hortensis) contained $\beta$-glucuronosyltransferases (GlcATs) involved in the synthesis of the carbohydrate moieties of arabinogalactan proteins (AGPs). The GlcATs transferred $\left[{ }^{14} \mathrm{C}\right] \mathrm{GlcA}$ from UDP- $\left[{ }^{14} \mathrm{C}\right] \mathrm{GlcA}$ on to $\beta$ - $(1 \rightarrow 3)$-galactan as an exogenous acceptor substrate, giving a specific activity of 50-150 $\mathrm{pmol} \mathrm{min}^{-1}$ (mg protein $)^{-1}$. The enzyme specimen also catalyzed the transfer of $\left[{ }^{14} \mathrm{C}\right] \mathrm{GlcA}$ on to an enzymatically modified AGP from mature radish root. Analysis of the transfer products revealed that the transfer of $\left[{ }^{14} \mathrm{C}\right] \mathrm{GlcA}$ occurred preferentially on to consecutive $(1 \rightarrow 3)$-linked $\beta$-Gal chains as well as single branched $\beta$ - $(1 \rightarrow 6)$-Gal residues through $\beta-(1 \rightarrow 6)$ linkages, producing branched acidic side chains. The enzymes also transferred $\left[{ }^{14} \mathrm{C}\right] \mathrm{GlcA}$ residues on to several oligosaccharides, such as $\beta$ $(1 \rightarrow 6)$ - and $\beta-(1 \rightarrow 3)$-galactotrioses. A trisaccharide, $\alpha$-L-Araf-( $1 \rightarrow 3)-\beta$-Gal-( $1 \rightarrow 6)-G a l$, was a good acceptor, yielding a branched tetrasaccharide, $\alpha$-L-Araf- $(1 \rightarrow 3)$ $[\beta-G l c A-(1 \rightarrow 6)]-\beta-G a l-(1 \rightarrow 6)-G a l$. We report the first
\end{abstract}

Sugars described in this paper belong to the D-series unless otherwise noted.

Electronic supplementary material The online version of this article (doi:10.1007/s00425-013-1959-0) contains supplementary material, which is available to authorized users.

M. Endo $\cdot$ T. Kotake $\cdot$ Y. Tsumuraya $(\square)$

Division of Life Science, Graduate School of Science and Engineering, Saitama University, 255 Shimo-okubo,

Sakura-ku, Saitama 338-8570, Japan

e-mail: tsumura@mail.saitama-u.ac.jp

Y. Watanabe $\cdot$ K. Kimura

Yakult Central Institute for Microbiological Research,

1796 Yaho, Kunitachi, Tokyo 186-8650, Japan in vitro assay system for $\beta$-GlcATs involved in the AG synthesis as a step toward full characterization and cloning.

Keywords Cell wall · Glucuronic acid . Glycosyltransferase $\cdot$ Raphanus

$\begin{array}{ll}\text { Abbreviations } & \\ \text { ABEE } & p \text {-Aminobenzoic acid ethyl ester } \\ \text { AGP } & \text { Arabinogalactan protein } \\ \text { L-Araf } & \text { L-Arabinofuranose } \\ \text { L-Ara-Gal-Gal } & \alpha \text {-L-Araf- }(1 \rightarrow 3)-\beta \text {-Gal- }(1 \rightarrow 6) \text {-Gal } \\ \text { DP } & \text { Degree of polymerization } \\ \text { GLC } & \text { Gas-liquid chromatography } \\ \text { GlcA } & \text { Glucuronic acid } \\ \text { GlcAT } & \text { Glucuronosyltransferase } \\ \text { MALDI-TOF/MS } & \begin{array}{l}\text { Matrix-assisted laser desorption/ } \\ \text { ionization time-of-flight mass }\end{array} \\ & \text { spectrometry } \\ \text { 4-Me-GlcA } & \text { 4-O-Methyl-glucuronic acid } \\ \text { GalT } & \beta-\text {-Galactosyltransferase }\end{array}$

\section{Introduction}

Arabinogalactan proteins (AGPs) are a family of proteoglycans found in plant cell walls, plasma membranes, and the extracellular matrix. They are suspected to be important in signaling and communication in plants, and are implicated in diverse functions such as cell-cell recognition, cell fate, embryogenesis, and xylem development (Clarke et al. 1979; Fincher et al. 1983; Nothnagel 1997; Seifert and Roberts 2007). AGPs are characterized by large carbohydrate components rich in Gal and L-arabinose (L-Ara) and protein components (core proteins: generally $<10 \%$ of total weight) rich in hydroxyproline, Ser, Thr, Ala, and Gly. 
The carbohydrate moieties [arabinogalactan (AG)] of AGPs have a common basic structure of $\beta-(1 \rightarrow 3)$-galactan backbones from which side chains of $\beta$ - $(1 \rightarrow 6)$-galactan branch off. The side chains are further substituted with L-Ara, glucuronic acid (GlcA), 4- $O$-methyl-glucuronic acid (4-Me-GlcA), and lesser amounts of other auxiliary sugars such as L-rhamnose and L-fucose. The uronosyl residues are found in nonreducing terminals attached to either $\beta$ - $(1 \rightarrow 6)$-galactan side chains or directly to $\beta$ - $(1 \rightarrow 3)$-galactan backbone chains as single residues through $\beta$ - $(1 \rightarrow 6)$ linkages in radish AGPs (Tsumuraya et al. 1990).

It is known that the rate of turnover of the carbohydrate moieties of AGPs is very rapid (Gibeaut and Carpita 1991). We have observed that the sugar composition and structure of the peripheral region of the carbohydrate moieties of AGPs in radish plants are organ-specific and developmentally regulated depending on the growth stage of the plants (Tsumuraya et al. 1988). These characteristic features of AGPs imply that the biosynthesis and degradation of AGPs in plant tissues are coordinately regulated and interdependent processes. A degradation process proceeding by concerted action of several glycosidases such as $\beta$-galactosidase and $\alpha$-L-arabinofuranosidase has been outlined in some plants (Kotake et al. 2005, 2006). On the other hand, the scenario for the biosynthesis process has not yet been described clearly. Since the carbohydrate moieties of AGPs are highly complex, there may be many glycosyltransferases for the synthesis of the glycan chains. These might include galactosyltransferases (GalTs) involved in the synthesis of the galactan $[\beta-(1 \rightarrow 3)(1 \rightarrow 6)$-galactan] chains as well as L-arabinosyl-, L-fucosyl-, and glucuronosyltransferases (Tan et al. 2012). However, our knowledge on the mechanisms and genes/enzymes responsible for the glycosylation of AGPs is limited. It is reasonable to assume that several different GalTs are required and act together in the synthesis of the galactan chains. Basu et al. (2013) and Oka et al. (2010) have detected and identified a GalT (Hyp:GalT) in Arabidopsis catalyzing the first step of the biosynthesis of the carbohydrate moieties by transferring Gal residues from UDP-Gal on to Hyp residues in the core proteins of AGPs. Subsequent chain elongation may proceed by addition of second $\mathrm{Gal}$ residues on to the first $\mathrm{Gal}$ residues by a different GalT (Gal:GalT). Qu et al. (2008) have identified a putative GalT, a member of the carbohydrate active enzyme (CAZy) glycosyltransferase (GT) family 31 , responsible for synthesizing $\beta-(1 \rightarrow 3)$-galactosyl linkages in AGPs. An Arabidopsis glycosyltransferase of GT31 (AtGALT31A) was found to possess GalT activity elongating $\beta-(1 \rightarrow 6)$-galactan side chains of AGPs (Geshi et al. 2013). However, the properties of these putative GalTs are not yet fully characterized, and the mechanism and regulation of the formation of $\beta-(1 \rightarrow 3)$, $\beta$-(1 $\rightarrow$ 6)-galactosyl-, and $\beta-(1 \rightarrow 3)(1 \rightarrow 6)$-branching linkages remain elusive. Another example, indicating the variety of enzymes involved, has come from the study of Wu et al. (2010), who have identified and characterized two AGP-specific $\alpha$-L- $(1 \rightarrow 2)$-fucosyltransferases encoded by AtFUT4 and AtFUT6 genes in Arabidopsis.

However, definitive identification and proof of biochemical action of more individual genes and enzymes are still required to understand the complex process of AG synthesis. No $\beta$-glucuronosyltransferase (GlcAT) involved in the synthesis of AGs has been either characterized or cloned so far. We describe an in vitro assay for the activities of $\beta$-GlcATs that catalyze the incorporation of GlcA residues from UDP-GlcA into the carbohydrate moieties of AGPs in primary radish roots with various polysaccharides and oligosaccharides as acceptor substrates. We propose that different $\beta$-GlcATs catalyze the transfer of GlcA on to $\beta$ $(1 \rightarrow 3)$-galactan backbones and $\beta$ - $(1 \rightarrow 6)$-galactan side chains of AGPs.

\section{Materials and methods}

\section{Plant and chemical materials}

Seeds of radish (Raphanus sativus L. var hortensis cv. Aokubi) were purchased from Tokita Seed and Plant (Saitama, Japan). Exo- $\beta-(1 \rightarrow 3)$-galactanase (EC 3.2.1.145) from Irpex lacteus (Tsumuraya et al. 1990), endo- $\beta-(1 \rightarrow$ 6)-galactanase (EC 3.2.1.164) from Trichoderma viride (Okemoto et al. 2003), $\alpha$-Larabinofuranosidase (EC 3.2.1.55) from Rhodotorula flava (Uesaka et al. 1978), and $\beta$-glucuronidase (EC 3.2.1.31) from Aspergillus niger (Kuroyama et al. 2001) were prepared in our laboratories. Uridine $5^{\prime}$-diphospho- $\left[{ }^{14} \mathrm{C}\right]$ glucuronic acid (UDP- $\left[{ }^{14} \mathrm{C}\right] \mathrm{GlcA}$; $10.9 \mathrm{GBq} \mathrm{mmol}^{-1}$ ) was purchased from PerkinElmer Life Sciences Japan (Tokyo, Japan), while unlabeled UDP-GlcA was obtained from Sigma-Aldrich Japan (Tokyo, Japan). Triton X-100 was obtained from Wako Pure Chemical Ind. (Osaka, Japan). EGTA, Hepes, and Mes were from Dojindo Laboratories (Kumamoto, Japan).

$\beta$-(1 $\rightarrow 3)-$ and $\beta$-(1 $\rightarrow$ 6)-Galactobioses, and -trioses were prepared from larch wood AG by partial acid hydrolysis (Aspinall et al. 1958b). The $\beta$ - $(1 \rightarrow 6)$-galactotetraose was prepared from gum ghatti (Aspinall et al. 1958a). Chemically synthesized $\beta$ - $(1 \rightarrow 6)$-galactopentaose was donated by Dr. Miura, Gifu Pharmaceutical University, Japan, and Professor Inazu, Tokai University, Japan (Miura et al. 2004). $\beta$-GlcA- $(1 \rightarrow 6)$-Gal and $\beta$-GlcA- $(1 \rightarrow 6)-\beta$ Gal-( $1 \rightarrow 6)$-Gal were prepared from acacia gum (Kuroyama et al. 2001). The $\alpha$-L-Araf-( $1 \rightarrow 3)-\beta$-Gal- $(1 \rightarrow 6)$-Gal (L-Ara.Gal.Gal) was prepared by enzymatic hydrolysis of 
the Smith degradation product of acacia gum with exo- $\beta$ $(1 \rightarrow 3$ )-galactanase (Tsumuraya et al. 1990). By repeated treatment of acacia gum, once to thrice Smith-degraded products were obtained (Sekimata et al. 1989; Tsumuraya et al. 1990), the last of which was essentially a linear $\beta$ $(1 \rightarrow 3$ )-galactan to which a small number (amounting to $7 \%)$ of singleton $\beta$-Gal branches through $\beta$ - $(1 \rightarrow 6)$-linkages were attached. AGPs from radish roots (AGP-IV) and leaves (AGP R-II) were prepared as in Tsumuraya et al. (1984, 1988). Digestion of the AGPs with $\alpha-\mathrm{L}-$ arabinofuranosidase provided enzymatically modified products. Further degradation of the modified root AGP with endo- $\beta$ - $(1 \rightarrow 6)$-galactanase yielded an additional product, which consisted of $\beta-(1 \rightarrow 3)$-galactan backbone chains substituted with short neutral and acidic $\beta-(1 \rightarrow 6)$-galactosyl side chains (Okemoto et al. 2003).

\section{Analytical methods}

Protein content was determined by the method of Bradford (1976) using BSA as the standard. Total sugar content was determined by the phenol-sulfuric acid method (Dubois et al. 1956). Sugars were separated by paper chromatography on Whatman No. 1 or 3MM paper with 1-butanol:AcOH:water (5:2:3, by vol.) as the solvent system. Sugar spots on the chromatograms were visualized with alkaline $\mathrm{AgNO}_{3}$. Radioactive spots on paper chromatograms were detected by a Bio-Image Analyzer model BAS-1000 (Fuji Photofilm Co., Tokyo, Japan).

Oligosaccharides were labeled at their reducing terminals with $p$-aminobenzoic acid ethyl ester (ABEE) according to the method of Matsuura and Imaoka (1988). The ABEE-derivatized sugars were analyzed by HPLC with a Shimadzu LC-10AS fitted with a fluorescence detector, model RF-10A $\mathrm{AL}_{\mathrm{XL}}$, and a column (250 mm long, $4.6 \mathrm{~mm}$ i.d.) of PALPAK Type N (Takara Bio Inc., Otsu, Japan). The column was eluted with acetonitrile:0.5 M acetic acid-triethylamine ( $\mathrm{pH} 7.3)(90: 10 ; \mathrm{v} / \mathrm{v}$; solvent A) and acetonitrile:0.5 M acetic acid-triethylamine ( $\mathrm{pH} 7.3$ ) (50:50; v/v; solvent B). The column was eluted with a linear gradient of solvent B from 0 to $100 \%$ over $50 \mathrm{~min}$ at a flow rate of $1 \mathrm{ml} \mathrm{min}{ }^{-1}$ and at $40{ }^{\circ} \mathrm{C}$. Fluorescence in the eluate was monitored at $305 \mathrm{~nm}$ (excitation) and $360 \mathrm{~nm}$ (emission). The apparent $M_{\mathrm{r}}$ of polysaccharides and oligosaccharides was estimated by size-exclusion HPLC with a refractive index detector (RID-10A) and tandem columns (each $300 \mathrm{~mm}$ long, $7.8 \mathrm{~mm}$ i.d.) of TSKgel G3000PW $\mathrm{XL}_{\mathrm{XL}}$ and $\mathrm{G}^{2500 \mathrm{PW}} \mathrm{XL}_{\mathrm{XL}}$ (Tosoh, Tokyo, Japan) as described previously (Kato et al. 2003). After passing through the columns and the detector, radioactive products were fractionated at 1-min intervals, and radioactivity $(\mathrm{dpm})$ was counted with a liquid scintillation counter.
Matrix-assisted laser desorption/ionization time-of-flight mass spectrometry (MALDI-TOF/MS) was performed using a Kompact MALDI IV instrument (Shimadzu, Kyoto, Japan) as described previously (Kuroyama et al. 2001). The structure of the transfer product was examined by NMR. ${ }^{1} \mathrm{H}-\mathrm{NMR}$ and ${ }^{13} \mathrm{C}$-NMR spectra were recorded on a JEOL ECA-500 spectrometer (Tokyo, Japan) equipped with an inverse 5-mm gradient probe in $\mathrm{D}_{2} \mathrm{O}$ at $30{ }^{\circ} \mathrm{C}$ (Kotake et al. 2005). Chemical shifts were measured using acetone ( $\delta 2.22 \mathrm{ppm}$ for ${ }^{1} \mathrm{H}-\mathrm{NMR}$ and $\delta 30.5 \mathrm{ppm}$ for ${ }^{13} \mathrm{C}-\mathrm{NMR}$ ) as internal reference. The proton and carbon signals were assigned by the DQF-COSY, 1D-TOCSY, DEPT135, HCHSQC, and HC-HMBC spectroscopy experiments. The signals for glycosylated carbons were confirmed by their markedly higher $\delta$ values compared with those for the corresponding non-glycosylated ones. Gas-liquid chromatography (GLC) of sugars as alditol acetates was performed with a Shimadzu gas chromatograph GC-6A fitted with a column $(0.28 \mathrm{~mm} \times 50 \mathrm{~m})$ of Silar $10 \mathrm{C}$, according to the method of Albersheim et al. (1967). The carboxyl groups of GlcA residues in permethylated oligosaccharides were reduced with LiAlH4 (Lewis et al. 1963), and the resulting methylated derivatives of Glc were analyzed by GLC.

\section{Assays of $\beta$-GlcAT}

A microsomal fraction from 6-day-old primary roots of radish was prepared according to the method of Misawa et al. (1996).

\section{Assay with radiolabeled UDP-GlcA}

The activities of $\beta$-GlcATs were assayed by the procedure used by Kato et al. (2003), which was adopted for radish $\beta$-GalT. A standard reaction mixture (total volume $30 \mu \mathrm{l}$ ) contained $2.0 \mathrm{mM}$ UDP- $\left[{ }^{14} \mathrm{C}\right] \mathrm{Glc} A(0.069 \mathrm{nmol}$ radiolabeled compound equivalent to $0.74 \mathrm{kBq}$, supplemented with $60 \mathrm{nmol}$ of unlabeled compound), $\beta$ - $(1 \rightarrow 3)$-galactan $\left(5 \mathrm{mg} \mathrm{ml}^{-1}\right.$ ), $30 \mathrm{mM} \mathrm{MnCl} 2,0.75 \%$ (w/v) Triton X-100, $160 \mathrm{mM}$ sucrose, $50 \mathrm{mM}$ galactono- $(1 \rightarrow 4)$-lactone, $20 \mathrm{mM} \mathrm{NaF}, 0.4 \mathrm{mM}$ DTT, $40 \mathrm{mM}$ Mes-KOH buffer (pH 6.0), and the microsomal fraction (protein content 30-50 $\mu \mathrm{g})$. Galactono-( $\rightarrow$ 4)-lactone was added to inhibit microsomal $\beta$-galactosidase(s) (Kato et al. 2003), which might degrade $\beta$-(1 $\rightarrow 3)$-galactan, AGP, and $\beta$-galactooligosaccharides provided as acceptor substrates in the reaction mixtures. The mixture was incubated at $25{ }^{\circ} \mathrm{C}$ for $60-120 \mathrm{~min}$. After the reaction was terminated with $0.3 \mathrm{M}$ acetic acid $(80 \mu \mathrm{l})$ containing $20 \mathrm{mM}$ EGTA, aliquots $(100 \mu \mathrm{l})$ were subjected to paper chromatography using $95 \%$ ethanol:1 $\mathrm{M}$ ammonium acetate $(2: 1, \mathrm{v} / \mathrm{v})$ as the solvent. The radiolabeled products, which were immobilized on the base line of chromatograms, were cut off, 
sonicated in water $(2 \mathrm{ml})$, and radioactivity was counted with a liquid scintillation counter (Ishikawa et al. 2000). Incorporation of $\left[{ }^{14} \mathrm{C}\right] \mathrm{GlcA}$ into other polysaccharides was measured similarly. Parallel assays were done under the standard assay conditions without addition of acceptors for estimation of $\beta$-GlcAT activity to endogenous acceptors. Activities with or without acceptors were corrected by respective time-zero controls. Unless otherwise noted, the data given are the net amounts of $\left[{ }^{14} \mathrm{C}\right] \mathrm{GlcA}$ incorporated into acceptors obtained by subtracting the amounts to endogenous acceptors from the total amounts in the presence of exogenous acceptors.

Incorporation of $\left[{ }^{14} \mathrm{C}\right] \mathrm{Glc} \mathrm{A}$ into oligosaccharide acceptors was measured under the same conditions as above except for acceptor oligosaccharides $(4 \mathrm{mM})$. The subsequent procedure followed the method of Misawa et al. (1996). The reaction was stopped by addition of cold water $(1 \mathrm{ml})$ and radiolabeled products were applied to a small column $(\sim 1 \mathrm{ml})$ of DEAE-cellulose (Serva, Heidelberg, Germany). After washing with cold water $(3 \mathrm{ml})$, the adsorbed radiolabeled transfer products were eluted in steps with $0.02 \mathrm{M} \mathrm{NaHCO}_{3}$ followed by $0.1 \mathrm{M} \mathrm{NaHCO}_{3}$ (each $4 \mathrm{ml}$ ) at room temperature. Each $1 \mathrm{ml}$ of the eluate was collected and radioactivity in $0.02 \mathrm{M}$ fractions was counted. Enzyme activity was corrected by controls incubated and treated in a similar manner without addition of acceptors.

Enzyme assays were done, at least, in duplicate and mean values were recorded.

\section{Assay with non-radiolabeled UDP-GlcA}

The action of $\beta$-GlcATs toward oligosaccharide acceptors was also examined by a fluorescence-labeling method. The reaction mixture $(30 \mu \mathrm{l})$ consisted of $2.0 \mathrm{mM}$ UDP-GlcA, $4 \mathrm{mM}$ oligosaccharide acceptors, the microsomal fraction, and the same concentrations of other components as the standard assay mixture without addition of sucrose and galactono- $(1 \rightarrow 4)$-lactone. The reaction was conducted for a prolonged time $(4 \mathrm{~h})$ and terminated by heating in a boiling water bath for $1 \mathrm{~min}$. The reaction products were derivatized with ABEE, filtered through a membrane filter (Chromatodisk 4A; Kurabo, Osaka, Japan), and subjected to HPLC analysis. The amount of product was expressed as the percentage of GlcA transferred from UDP-GlcA to acceptor oligosaccharides.

Analysis of transfer products

\section{Product from polysaccharide acceptors}

We found that the commercial UDP- $\left[{ }^{14} \mathrm{C}\right] \mathrm{GlcA}$ specimen contained a small amount of impurity that interfered with the analysis of the products formed by transfer of $\left[{ }^{14} \mathrm{C}\right]$ GlcA. Therefore, the specimen was purified by preparative paper chromatography using $95 \%$ ethanol:1 M ammonium acetate $(2: 1, \mathrm{v} / \mathrm{v})$ as the solvent as described above. The areas corresponding to UDP- $\left[{ }^{14} \mathrm{C}\right] \mathrm{GlcA}$ were cut off, extracted with hot water, centrifuged, concentrated, and used for the following experiments. A large-scale reaction mixture $(150 \mu \mathrm{l}$, membranous protein $770 \mu \mathrm{g})$ containing 15 times the amounts of UDP- $\left[{ }^{14} \mathrm{C}\right] \mathrm{GlcA}$ $(11.1 \mathrm{kBq})$ and $\beta-(1 \rightarrow 3)$-galactan $\left(5 \mathrm{mg} \mathrm{ml}^{-1}\right)$ and the same concentrations of other components as in the standard assay mixture was incubated at $25{ }^{\circ} \mathrm{C}$ for $24 \mathrm{~h}$. After heating the reaction mixture, the transfer product was isolated by paper chromatography as above. The radiolabeled products immobilized on the base line of chromatograms were extracted with hot water, centrifuged, and concentrated to dryness. The amount of $\left[{ }^{14} \mathrm{C}\right] \mathrm{GlcA}$ incorporated into the transfer product was $5.6 \%$ of initial UDP- $\left[{ }^{14} \mathrm{C}\right] \mathrm{GlcA}$. Another transfer product was obtained in a similar manner as above using $\alpha$-L-arabinofuranosidase followed by endo- $\beta-(1 \rightarrow 6)$-galactanase-digested root AGP as the acceptor, where $\left[{ }^{14} \mathrm{C}\right] \mathrm{GlcA}$ transfer was $1.6 \%$ of initial UDP- $\left[{ }^{14} \mathrm{C}\right]$ GlcA.

A portion $(3,000-7,000 \mathrm{dpm})$ of each extract was digested with either exo- $\beta$ - $(1 \rightarrow 3)$-galactanase (17 milliunits) or $\beta$-glucuronidase (9 milliunits) or both enzymes in a reaction mixture $(20 \mu \mathrm{l})$ containing $12 \mathrm{mM}$ sodium acetate buffer ( $\mathrm{pH} 4.6$ ), at $37^{\circ} \mathrm{C}$ for $24 \mathrm{~h}$. After heating the reaction mixture, a part of the hydrolysate was separated by paper chromatography and analyzed for radioactivity with a Bio-Image Analyzer. Another part was subjected to sizeexclusion HPLC and analyzed for radioactivity with a liquid scintillation counter.

\section{Products from oligosaccharide acceptors}

A large reaction mixture ( 3 or $1.5 \mathrm{ml}$ ) containing 10 or $6 \mathrm{mg}$ membrane protein, respectively, $2 \mathrm{mM}$ UDP-GlcA, and $4 \mathrm{mM} \beta$-(1 $\rightarrow 6)$ - or $\beta$-(1 $\rightarrow 3)$-galactotriose, or L-Ara.Gal.Gal as acceptor, and the same concentrations of other components as the standard assay mixture without sucrose and galactono-( $1 \rightarrow 4)$-lactone was incubated at $25{ }^{\circ} \mathrm{C}$ for $24 \mathrm{~h}$. After heat-inactivation of the reaction, the transfer products in the reaction mixture were derivatized with ABEE and partially purified on a column $(92 \mathrm{~cm}$ long, $1.6 \mathrm{~cm}$ i.d.) of Sephadex G-15 (GE Healthcare BioSciences, Tokyo, Japan) eluted with $10 \mathrm{mM}$ ammonium bicarbonate. The fractions containing the transfer products were concentrated by evaporation and applied to a PresepC C-18 (ODS) cartridge (Wako Pure Chemical Ind.). The cartridge was washed with $0.1 \mathrm{M}$ acetic acid, and the products were eluted with $20 \%$ acetonitrile and concentrated. The products were then purified by HPLC. The products 
recovered were treated with the cartridge once more and dried.

The transfer products were analyzed for their structure by MALDI-TOF/MS, NMR, methylation analysis, and enzymatic hydrolysis with $\beta$-glucuronidase or $\alpha$-Larabinofuranosidase. The enzymatic hydrolysis products were analyzed by HPLC.

\section{Results}

A schematic overview of this study is shown in Fig. 1, which includes structural models of $\beta$ - $(1 \rightarrow 3)$-galactan and radish $\mathrm{AG}$, and of the oligosaccharides used in this study as efficient acceptor substrates. The figure also shows the GlcA transfer action of radish $\beta$-GlcATs on to these acceptors, and the analytical diagram of $\left[{ }^{14} \mathrm{C}\right] \mathrm{GlcA}$ transfer products by enzymatic hydrolyses (see Fig. 4).

\section{$\beta$-GlcAT activities in microsomes}

The activities of $\beta$-GlcATs were assayed by incubating a microsomal fraction from 6-day-old primary roots of radish under standard assay conditions with $\beta$ - $(1 \rightarrow 3)$-galactan as the acceptor substrate. The transfer products were separated by paper chromatography from unreactive UDP$\left[{ }^{14} \mathrm{C}\right] \mathrm{GlcA}$ and its degraded product, and their radioactivity was measured. Enzyme product with $\beta$ - $(1 \rightarrow 3)$-galactan increased proportionally up to $240 \mathrm{~min}$ (Fig. 2a), and activity increased proportionally to the amount of protein up to $150 \mu \mathrm{g}$ under an incubation time of $60 \mathrm{~min}$ (Fig. 2b). Activity for endogenous acceptors increased proportionally, but was low (about one-tenth) in comparison with that of the standard reaction. Control experiments were done under standard conditions either without microsomes or with heat-denatured membrane proteins instead of intact microsomes. These gave no detectable activity. The specific activity (after subtraction of activity toward endogenous acceptors) of radish $\beta$-GlcATs was usually in a range of 50-150 pmol $\mathrm{min}^{-1}(\mathrm{mg} \text { protein })^{-1}$ [i.e., $8-25$ pkat $(\mathrm{mg}$ protein $)^{-1}$ ], depending on the microsomal preparations. Actual activity to endogenous acceptors was in a range of 5-15 $\mathrm{pmol} \mathrm{min}^{-1}$ (mg protein) $)^{-1}$. The total activity differed depending on radish organs after 6-day cultivation: it was lower in cotyledons (14\%) and hypocotyls (36\%), where the specific activity of root GlcAT is taken as $100 \%$.

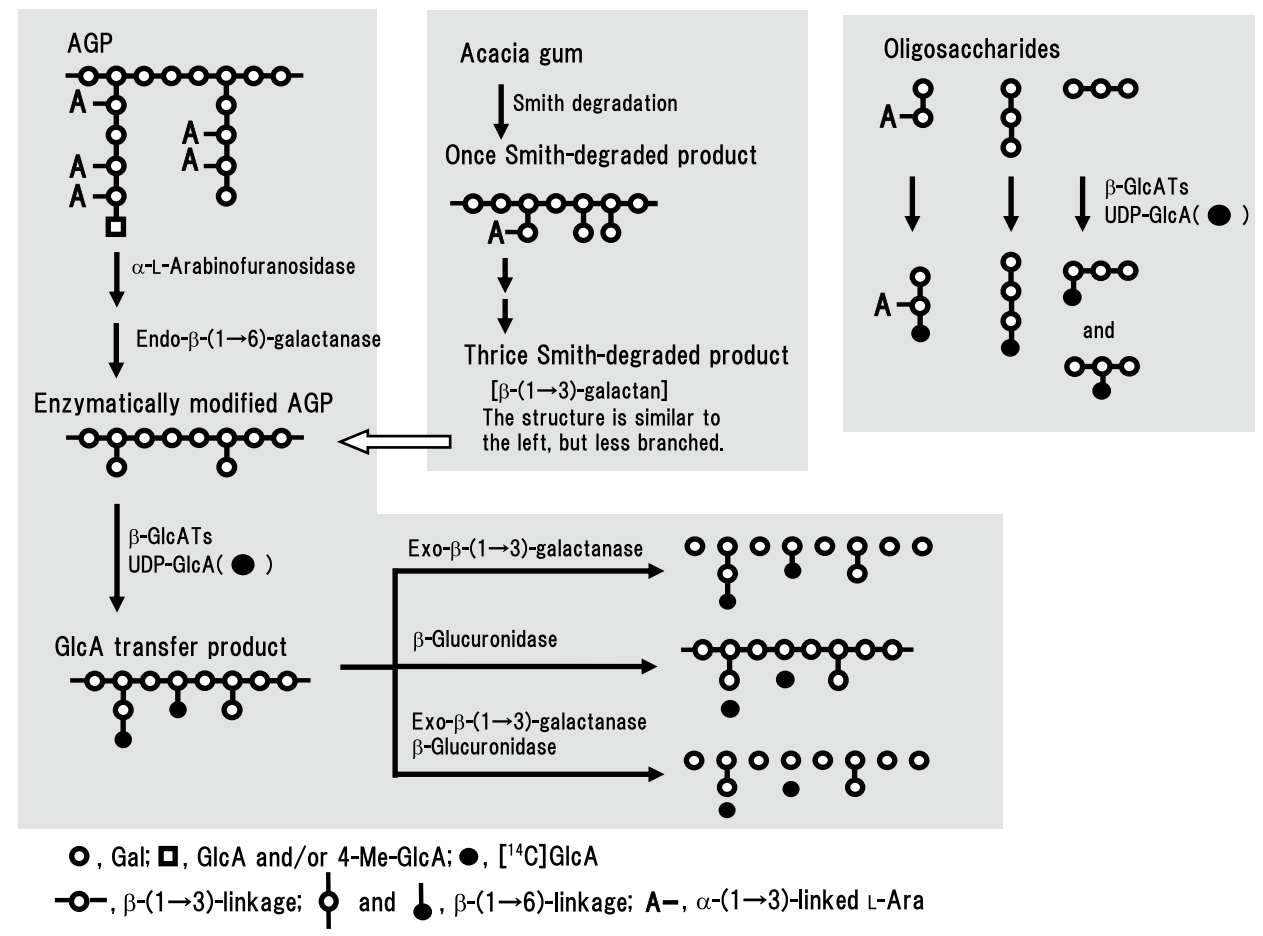

Fig. 1 Schematic overview of the transfer of GlcA from UDPGlcA on to $\beta$ - $(1 \rightarrow 3)$-galactan, enzymatically modified AGP, and oligosaccharides by the action of radish $\beta$-GlcATs. Once to thrice Smith-degraded products were prepared from acacia gum: thrice Smith-degraded product was essentially $\beta$ - $(1 \rightarrow 3)$-galactan containing a small amount $(7 \%)$ of single Gal residues attached through $\beta$ $(1 \rightarrow 6)$ linkages. The enzymatically modified AGP was prepared by successive digestion of radish root AGP with $\alpha$-L-arabinofuranosidase and endo- $\beta-(1 \rightarrow 6)$-galactanase. More detailed structural models are shown in a reference (Kitazawa et al. 2013 and the supplemental data for it). The $\left[{ }^{14} \mathrm{C}\right] \mathrm{GlcA}$ transfer products produced by the enzymatic action were analyzed by enzymatic hydrolysis with exo- $\beta$ $(1 \rightarrow 3)$-galactanase, $\beta$-glucuronidase, and successive digestion with exo- $\beta$ - $(1 \rightarrow 3)$-galactanase and $\beta$-glucuronidase (see Fig. 4) 

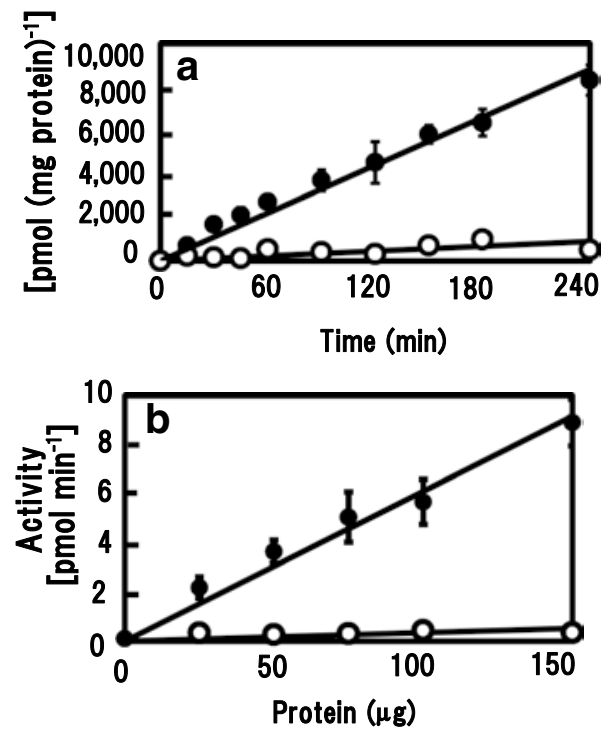

Fig. 2 Activity of $\beta$-GlcATs in microsomes from radish primary roots. a The microsomes (protein, $50 \mu \mathrm{g}$ ) were incubated under standard assay conditions with $\beta-(1 \rightarrow 3)$-galactan as exogenous acceptor (closed circles) and with endogenous acceptors (open circles) for varying times up to $240 \mathrm{~min}$. After $240 \mathrm{~min}$, the amount of $\left[{ }^{14} \mathrm{C}\right]$ GlcA transferred to $\beta$ - $(1 \rightarrow 3)$-galactan was about $0.6 \%$ of initial UDP- $\left[{ }^{14} \mathrm{C}\right] \mathrm{GlcA}$. The data are the mean $\pm \mathrm{SE}$ of quadruple experiments. b Relationship between enzyme activity and protein concentration. Various amounts of microsomal protein were incubated under

The specific activity of $\beta$-glucuronidase(s) in the microsomes was assayed in a mixture containing $1 \mathrm{mM}$ $p$-nitrophenyl- $\beta$-glucuronide, $50 \mathrm{mM}$ acetate buffer $(\mathrm{pH} 4.6)$, and the microsomal fraction at $25{ }^{\circ} \mathrm{C}$ for $4 \mathrm{~h}$ (Kuroyama et al. 2001). The hydrolysis activity was $58 \mathrm{pmol} \min ^{-1}$ (mg protein) ${ }^{-1}$, almost the same magnitude as that of $\beta$-GlcATs. The enzyme seems to degrade, partially, the transfer products formed by the action of $\beta$-GlcATs, thus leading to an underestimation of the activities of $\beta$-GlcATs.

\section{Properties of $\beta$-GlcATs}

The effect of $\mathrm{pH}$ on the activity of the $\beta$-GlcATs was examined with three kinds of buffers of various $\mathrm{pH}$ at a final concentration of $80 \mathrm{mM}$ under standard assay conditions with $\beta$-(1 $\rightarrow 3)$-galactan as acceptor. The optimum $\mathrm{pH}$ for $\beta$-GlcAT action was around 6.0 (Fig. 2c). Enzyme activity was optimal at $20-25^{\circ} \mathrm{C}$ (Fig. 2d).

The effect of addition of various detergents on $\beta$-GlcAT activity was examined at $0.5 \%(\mathrm{w} / \mathrm{v})$ final concentration under standard assay conditions. The following data were obtained, where the number in parentheses represents the relative activity, taking that obtained without detergent as unity: none (1), Triton X-100 (3.7), digitonin (3.6), Zwittergent 3-16 (2.2), $n$-octyl- $\beta$-thioglucoside (1.5). The effect of various concentrations $(0.05-1.5 \%, w / v)$ of Triton X-100

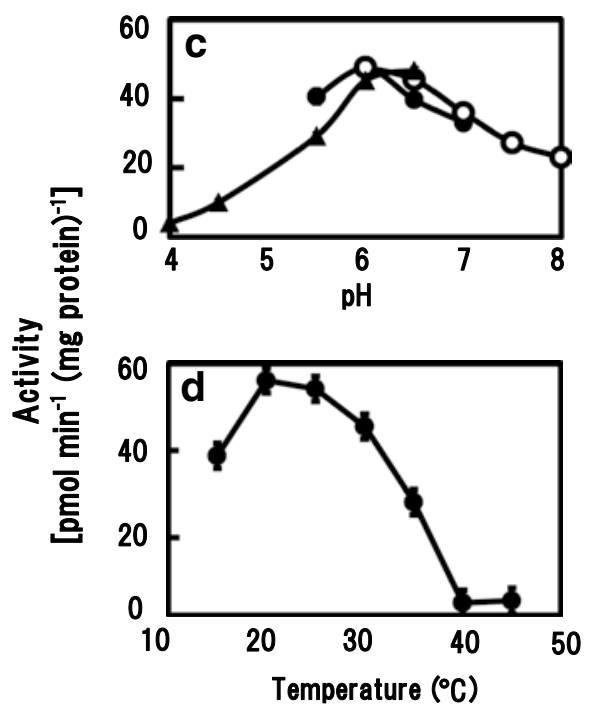

standard conditions for $60 \mathrm{~min}$. $\mathbf{c}$ Effects of $\mathrm{pH}$ on enzyme activity. Activity-pH curves result from experiments with buffers $(80 \mathrm{mM})$ having different $\mathrm{pH}$ values under standard conditions for 120 min. Closed circles Mes-KOH, open circles Hepes-KOH, closed triangles acetate. d Activity-temperature curves result from incubations at different temperatures under standard assay conditions for $120 \mathrm{~min}$. Note that the activity plotted for $\beta$ - $(1 \rightarrow 3)$-galactan includes that for endogenous acceptors in $\mathbf{a}$ and $\mathbf{b}$

on enzyme activity was measured. The activity increased with the concentration of Triton X-100 but reached a plateau at $0.75 \%$ with fivefold higher activity than without the detergent. It seems likely that the inclusion of Triton X-100 in reaction mixtures solubilizes membrane-bound $\beta$-GlcAT proteins or loosens them to facilitate access to substrates. We tested for this possibility by mixing the microsomes $(0.6 \mathrm{ml} ; 1.6 \mathrm{mg}$ protein) with the standard assay mixture except for substrates. The mixture was kept at $0{ }^{\circ} \mathrm{C}$ for $30 \mathrm{~min}$, and centrifuged at $100,000 \mathrm{~g}$ for $1 \mathrm{~h}$. The proportion of total activity recovered in the supernatant and the pellet was 50 and $30 \%$ of initial activity, indicating that about one-third of $\beta$-GlcAT protein remains in a membrane-bound form in reaction mixtures.

The effect of various cations on $\beta$-GlcAT activity was examined by incubation at $5 \mathrm{mM}$ final concentration. The following results were obtained, taking that obtained without cation as unity: none (1), $\mathrm{Mn}^{2+}(2.8), \mathrm{Mg}^{2+}(2.3), \mathrm{Zn}^{2+}$ (1.6), $\mathrm{Co}^{2+}$ (1.5), $\mathrm{Ca}^{2+}$ (1.2). Apparently, $\mathrm{Mn}^{2+}$ and $\mathrm{Mg}^{2+}$ enhanced activity. The effects of various concentrations (1-70 mM) of $\mathrm{Mn}^{2+}$ were examined. Activity increased with increasing concentration of $\mathrm{Mn}^{2+}$, reaching a maximum at $30-40 \mathrm{mM}$ concentration (4 times that without the ion), then gradually declined at higher concentrations.

The effect of the UDP- $\left[{ }^{14} \mathrm{C}\right] \mathrm{Glc} A$ concentration (0-3 mM) on $\beta$-GlcAT activity was examined. Apparent $K_{\mathrm{m}}$ and $V_{\max }$ values for UDP-GlcA, calculated according to 


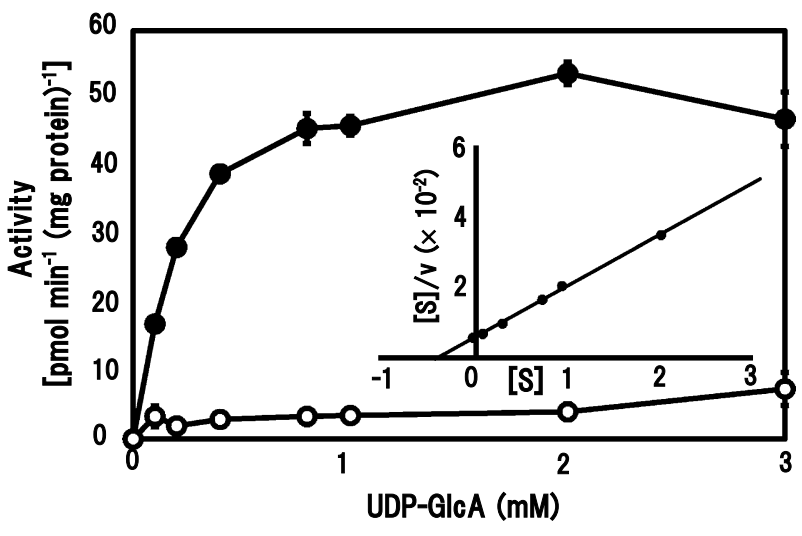

Fig. 3 Effect of UDP-GlcA concentration on $\beta$-GlcAT activities. Enzyme activity was measured under standard assay conditions by incubation of the membranes (protein, $50 \mu \mathrm{g}$ ) at various concentrations of UDP- $\left[{ }^{14} \mathrm{C}\right] \mathrm{GlcA}$ for $120 \mathrm{~min}$. The inset represents the HanesWoolf plot for the data. Refer Fig. 2 for the symbols

the Hanes-Woolf plot, were $0.26 \mathrm{mM}$ and $60 \mathrm{pmol} \mathrm{min}^{-1}$ (mg protein $)^{-1}$, respectively (Fig. 3). Kinetic analysis for the effect of concentrations $\left(0-12 \mathrm{mg} \mathrm{ml}^{-1}\right)$ of $\beta$ $(1 \rightarrow 3)$-galactan did not give a saturated curve of reaction velocity and showed almost linearly increasing activity, $150 \mathrm{pmol} \mathrm{min}^{-1}$ (mg protein) $)^{-1}$ at $12 \mathrm{mg} \mathrm{ml}^{-1}$. Hence, significant kinetic parameters were not obtained.

The following sugars inhibited $\beta$-GlcAT activities at high $(50 \mathrm{mM})$ concentration, where that obtained without sugars is taken as standard: none (1), galacturonic acid (0.003), glucono-(1 $\rightarrow$ 5)-lactone (0.02), glucuronic acid 1-phosphate (0.54). However, these sugars did not affect the activity as much at low $(10 \mathrm{mM})$ concentration. GlcA did not affect activity even at $50 \mathrm{mM}$ concentration. Sucrose $(160 \mathrm{mM})$ and galactono- $(1 \rightarrow 4)$-lactone $(50 \mathrm{mM})$, which were included in the standard assay mixture, neither enhanced nor inhibited enzyme activities.

\section{Substrate specificity}

Various AGPs, their enzymatically modified derivatives, and polysaccharides were examined for efficiency as acceptor substrates (Table 1). Among these AGPs and polysaccharides, $\beta-(1 \rightarrow 3)$-galactan used as an acceptor for the standard enzyme assay showed the highest activity. Native acacia gum was a poor substrate, but enzyme activity tended to increase with the proportion of $(1 \rightarrow 3)$-linked $\beta$-Gal residues, which was increased by successive Smith degradations. However, once Smith-degraded product was a better acceptor than twice degraded product. The once degraded product has a lower proportion of $(1 \rightarrow 3)$-linked $\beta$-Gal residues than twice Smith-degraded product, but has $\alpha$-L-Araf residues $(21 \mathrm{~mol} \%)$ attached to $\beta$ - $(1 \rightarrow 6)$-galactosyl side chains through $(1 \rightarrow 3)$ linkages (Tsumuraya
Table 1 Effect of various AGPs and polysaccharides on the activity of $\beta$-GlcATs

\begin{tabular}{|c|c|}
\hline Acceptor $^{\mathrm{a}}$ & Enzyme activity $(\%)^{\mathrm{b}}$ \\
\hline \multicolumn{2}{|l|}{ Acacia gum } \\
\hline Native & 25 \\
\hline Once Smith-degraded product & 63 \\
\hline Twice Smith-degraded product & 36 \\
\hline Thrice Smith-degraded product & 100 \\
\hline \multicolumn{2}{|l|}{ Radish root AGP } \\
\hline Native & 26 \\
\hline$\alpha$-L-Arabinofuranosidase treated & 50 \\
\hline $\begin{array}{l}\alpha \text {-L-Arabinofuranosidase } \\
\quad+\text { endo- } \beta-(1 \rightarrow 6) \text {-galactanase treated }\end{array}$ & 91 \\
\hline $\begin{array}{l}\alpha \text {-L-Arabinofuranosidase } \\
\quad+\text { exo- } \beta-(1 \rightarrow 3) \text {-galactanase treated }\end{array}$ & 9 \\
\hline \multicolumn{2}{|l|}{ Radish leaf AGP } \\
\hline Native & 8 \\
\hline$\alpha$-L-Arabinofuranosidase treated & 12 \\
\hline Larch wood AG & 8 \\
\hline Soybean arabinan-galactan & 0 \\
\hline Oat-spelt xylan & 60 \\
\hline
\end{tabular}

${ }^{\text {a }}$ Concentrations of acceptors were $5 \mathrm{mg} \mathrm{ml}^{-1}$

b Activity expressed relative to that for thrice Smith-degraded product. In other words, total activity toward almost unadorned $\beta$ - $(1 \rightarrow 3)$-galactan, $59 \mathrm{pmol} \mathrm{min}^{-1}(\mathrm{mg} \text { protein })^{-1}$, was taken as $100 \%$. The mixtures were incubated at $25^{\circ} \mathrm{C}$ for $120 \mathrm{~min}$. Activity of

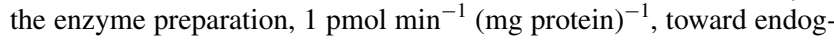
enous acceptors is subtracted

et al. 1990). We suggest that the $\alpha$-L-Ara $f$ residues facilitate the transfer of GlcA residues from UDP-GlcA, causing the enhancement of $\beta$-GlcAT activity. This is consistent with the result obtained when L-Ara-containing galactooligosaccharide (L-Ara.Gal.Gal) was used as an acceptor (see below).

Native root AGP was a poor acceptor but turned into a better substrate when Gal residues were exposed by enzymatic removal of $\alpha$-L-Araf residues (content in the AGP, $24 \mathrm{~mol} \%$; Tsumuraya et al. 1988) that are attached at $O-3$ of nonreducing terminal and internal $\beta$-(1 $\rightarrow$ 6)-galactosyl side chains ranging from single to, at least, $20 \mathrm{Gal}$ residues with or without caps of single 4-Me-GlcA residues at nonreducing terminals (Tsumuraya et al. 1990; Haque et al. 2005). Subsequent digestion of the $\alpha$-L-arabinofuranosidase-modified AGP by endo- $\beta-(1 \rightarrow 6)$-galactanase removes such $\beta$ $(1 \rightarrow 6)$-galactosyl side chains and leaves short stubs [mostly a single unit long, some of which are substituted with 4-Me-GlcA residues (Okemoto et al. 2003)]. Consistent with the results obtained for the series of chemically modified acacia gum, $\alpha$-L-arabinofuranosidase-modified root AGP showed enhanced efficiency, half the enzyme 
activity of $\beta$ - $(1 \rightarrow 3)$-galactan. Similar results were obtained for the case of leaf AGP. The $\alpha$-L-arabinofuranosidaseand $\beta$ - $(1 \rightarrow 6)$-galactanase-modified root AGP served as a very effective acceptor, with activity amounting to as much as $90 \%$ of that of $\beta-(1 \rightarrow 3)$-galactan. These results suggest that radish primary root GlcATs prefer long consecutive $(1 \rightarrow 3)$-linked $\beta$-Gal residues as acceptor substrates for GlcA transfer. On the other hand, when the $\alpha$-L-arabinofuranosidase-modified root AGP was further digested with exo- $\beta-(1 \rightarrow 3)$-galactanase, the resulting AGP showed lower efficiency than the native AGP. This exo- $\beta$ - $(1 \rightarrow 3)$-galactanase-modified AGP has lost more than $90 \%$ of the sugar constituents of the native form and represents the core portion of the AGP with only a small portion of $(1 \rightarrow 3)$-linked $\beta$-Gal residues remaining (Tsumuraya et al. 1990). Larch wood AG and soybean arabinan-galactan (Sekimata et al. 1989) were unreactive, but oat-spelt xylan (Sigma-Aldrich, Japan) served as a good acceptor. We confirmed that the xylan specimen was free from AGPs by gel diffusion assay with $\beta$-galactosyl Yariv reagent (Biosupplies, Bundoora, Australia), a dye specific to AGPs (Nothnagel 1997). Our result suggests that the xylan acted as an acceptor for $\alpha$-GlcAT(s) involved in the synthesis of glucuronoxylan.

Table 2 summarizes the activities of $\beta$-GlcATs with Gal and various galactooligosaccharides differing in type of linkage and chain length. Clearly, Gal was a poor acceptor substrate, and $\beta-(1 \rightarrow 6)-$ and $\beta-(1 \rightarrow 3)$-galactobioses were also seen to be unreactive when the amount of $\left[{ }^{14} \mathrm{C}\right] \mathrm{GlcA}$ detected in the control reaction incubated without acceptors was taken into account. The activity,

Table 2 Substrate specificity of radish ß-GlcATs toward various oligosaccharide acceptors

\begin{tabular}{lc}
\hline Acceptor & $\left.\begin{array}{l}\text { Enzyme activity } \\
{[\mathrm{pmol} \mathrm{min}}\end{array} \mathrm{m}^{-1}(\mathrm{mg} \text { protein })^{-1}\right]^{\mathrm{a}}$ \\
\hline Control (endogenous acceptors) & 45 \\
Gal & 49 \\
$\beta-(1 \rightarrow 6)$-galactobiose & 43 \\
$\beta-(1 \rightarrow 6)$-galactotriose & 89 \\
$\beta-(1 \rightarrow 6)$-galactotetraose & 84 \\
$\beta-(1 \rightarrow 6)$-galactopentaose & 104 \\
$\beta-(1 \rightarrow 3)$-galactobiose & 58 \\
$\beta-(1 \rightarrow 3)-$ galactotriose & 90 \\
$\alpha-\mathrm{L}-$ Araf-(1 $\rightarrow$ 3)- $\beta$-Gal-(1 $\rightarrow 6)-$ & 93 \\
Gal (L-Ara.Gal-Gal) & \\
\hline
\end{tabular}

a Activity expressed as specific activity calculated based on the amounts of $\left[{ }^{14} \mathrm{C}\right] \mathrm{GlcA}$ transfer products eluted from ion-exchange chromatography of the reaction mixtures. The reaction was carried out at $25{ }^{\circ} \mathrm{C}$ for $120 \mathrm{~min}$. The high control value observed for incubation without acceptors may derive from $\left[{ }^{14} \mathrm{C}\right] \mathrm{GlcA}$ transferred to endogenous acceptors as well as free $\left[{ }^{14} \mathrm{C}\right] \mathrm{GlcA}$ due to partial degradation of UDP- $\left[{ }^{14} \mathrm{C}\right] \mathrm{Glc} A$ during incubation however, increased with the increasing chain length of both $(1 \rightarrow 6)$ - and $\beta$ - $(1 \rightarrow 3)$-linked oligosaccharides as evidenced by the high activity observed for $\beta$ - $(1 \rightarrow 6)$-galactooligosaccharides with degree of polymerization (DP) $3-5$ and $\beta$ - $(1 \rightarrow 3)$-galactotriose. As observed for polymer acceptors, radish $\beta$-GlcATs seem to prefer consecutive $(1 \rightarrow 3)$-linked $\beta$-Gal residues. They also appear to prefer consecutive $(1 \rightarrow 6)$-linked $\beta$-Gal residues. This contrasts with the results observed for polymer acceptors, in which native root AGP and its $\alpha$-L-arabinofuranosidase-modified derivative served as less efficient acceptors than $\alpha-\mathrm{L}-$ arabinofuranosidase- and $\beta-(1 \rightarrow 6)$-galactanase-modified AGP with shortened $\beta-(1 \rightarrow 6)$-galactosyl side chains. In addition, we observed that an L-Ara-containing galactooligosaccharide, L-Ara.Gal.Gal, served as a better acceptor than $\beta$-(1 $\rightarrow 6)$-galactobiose, suggesting that the L-Araf residues facilitate the transfer of GlcA residues from UDPGlcA catalyzed by $\beta$-GlcATs.

Analysis of transfer products obtained with $\beta$ - $(1 \rightarrow 3)$-galactan and a modified AGP

The products of $\left[{ }^{14} \mathrm{C}\right] \mathrm{GlcA}$ transfer on to $\beta-(1 \rightarrow 3)$ galactan and $\alpha$-L-arabinofuranosidase- and $\beta-(1 \rightarrow 6)$ galactanase-modified AGP by the action of radish $\beta$-GlcATs were characterized by enzymatic analysis. The transfer products formed from $\beta-(1 \rightarrow 3)$-galactan were digested with either exo- $\beta-(1 \rightarrow 3)$-galactanase, or $\beta$-glucuronidase, or exo- $\beta$ - $(1 \rightarrow 3)$-galactanase followed by $\beta$-glucuronidase (Fig. 4). Separation of the hydrolysis products on paper chromatography showed main radiolabeled sugars corresponding to $\beta$-GlcA- $(1 \rightarrow 6)$-Gal and $\beta$-GlcA- $(1 \rightarrow 6)-\beta-G a l-(1 \rightarrow 6)-G a l$ after exo- $\beta$ $(1 \rightarrow 3)$-galactanase treatment. The oligosaccharides gave $\left[{ }^{14} \mathrm{C}\right] \mathrm{GlcA}$ as the sole radioactive sugar after subsequent digestion with $\beta$-glucuronidase. This was also the case for the enzymatically modified AGP (Fig. 4c). Based on the substrate specificity of the enzymes (Tsumuraya et al. 1990; Kuroyama et al. 2001), radiolabeled $\beta$-GlcA- $(1 \rightarrow 6)$-Gal arises from single units of $\left[{ }^{14} \mathrm{C}\right] \mathrm{GlcA}$ transferred on to nonreducing terminals and/or internal Gal residues along $\beta$-(1 $\rightarrow 3)$-galactan chains through $\beta$ - $(1 \rightarrow 6)$ linkages. We suggest that radiolabeled $\beta$-GlcA- $(1 \rightarrow 6)-\beta$ Gal-(1 $\rightarrow$ 6)-Gal derived from $\left[{ }^{14} \mathrm{C}\right]$ GlcA transferred on to single-unit $\beta$ - $(1 \rightarrow 6)$-galactosyl branches attached to $\beta-(1 \rightarrow 3)$-galactan and $\alpha$-L-arabinofuranosidase- and $\beta$ $(1 \rightarrow 6)$-galactanase-modified AGP through $\beta$ - $(1 \rightarrow 6)$ linkages, as schematically depicted in Fig. 1.

The hydrolysis products were also analyzed by sizeexclusion HPLC (Fig. 5). The intact radiolabeled transfer product formed from the enzymatically modified AGP emerged as a peak $\left(M_{\mathrm{r}}\right.$ around 60,000$)$ at the same point as the acceptor substrate (Okemoto et al. 2003). Digestion 


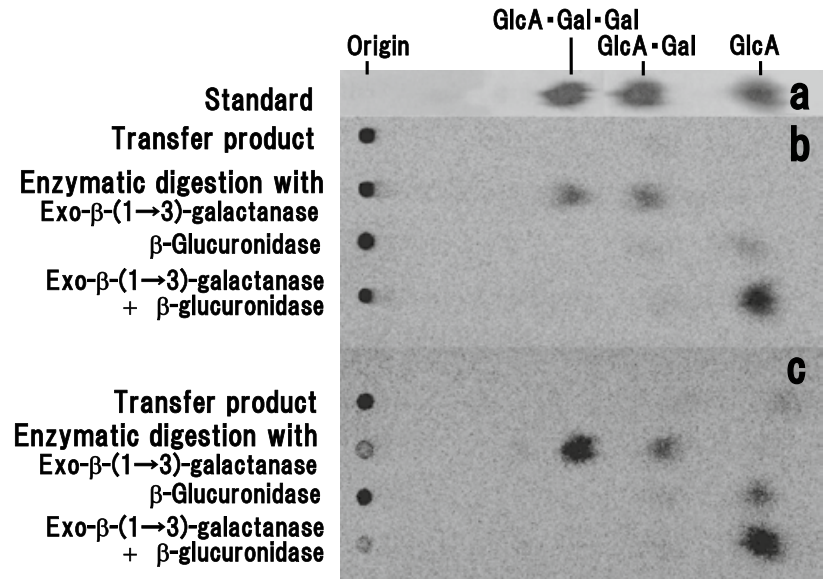

Fig. 4 Analyses of the enzymatic hydrolysates of the $\left[{ }^{14} \mathrm{C}\right] \mathrm{GlcA}$ transfer products by paper chromatography. a Standard sugars: GlcA, $\beta$-GlcA-(1 $\rightarrow$ 6)-Gal, and $\beta$-GlcA- $(1 \rightarrow 6)-\beta$-Gal$(1 \rightarrow 6)$-Gal (from right to left). These sugars were detected by the alkaline $\mathrm{AgNO}_{3}$ method. The transfer product formed from $\beta$ $(1 \rightarrow 3)$-galactan $(\mathbf{b})$ and a root AGP digested successively with $\alpha$-L-arabinofuranosidase and endo- $\beta-(1 \rightarrow 6)$-galactanase $(\mathbf{c})$ as exogenous acceptors were digested, respectively, with enzymes, and the pattern of radioactivity was analyzed by Bio-Image Analyzer. All intact transfer products and their digestion products with exo- $\beta$ $(1 \rightarrow 3)$-galactanase, $\beta$-glucuronidase, and successive digestion with exo- $\beta-(1 \rightarrow 3)$-galactanase and $\beta$-glucuronidase are shown

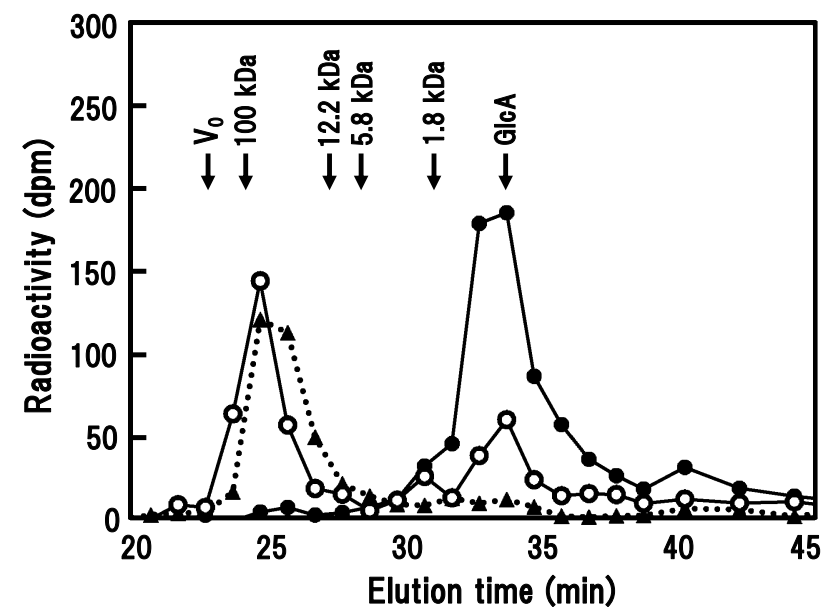

Fig. 5 Analysis of the $\left[{ }^{14} \mathrm{C}\right] \mathrm{GlcA}$ transfer product and its enzymatically degraded products by size-exclusion HPLC. Elution profile of the $\left[{ }^{14} \mathrm{C}\right] \mathrm{GlcA}$ transfer product formed from a root AGP digested successively with $\alpha$-L-arabinofuranosidase and endo- $\beta-(1 \rightarrow 6)$-galactanase as the exogenous acceptor is shown. Dotted lines Intact transfer product, open circles digestion with $\beta$-glucuronidase, closed circles digestion with exo- $\beta-(1 \rightarrow 3)$-galactanase and $\beta$-glucuronidase. The eluates were fractionated and their radioactivity was counted. The column system was calibrated with high- $M_{\mathrm{r}}$ dextran $\left(V_{\mathrm{o}}\right)$ and pullulans with known $M_{\mathrm{r}}$, (Shodex Standard P-82; Showa Denko, Tokyo, Japan), and GlcA of the transfer product with $\beta$-glucuronidase liberated only small amounts of free $\left[{ }^{14} \mathrm{C}\right] \mathrm{GlcA}$ and did not diminish the high- $M_{\mathrm{r}}$ transfer product. This had also been observed in paper chromatographic analyses. The suppression of hydrolysis is apparently caused by the limitation of access of the enzyme to uronosyl residues located at short $\beta$ - $(1 \rightarrow 6)$-galactosyl side chains in the modified AGP (Haque et al. 2005). In contrast, successive digestion of the transfer product with exo- $\beta-(1 \rightarrow 3)$-galactanase and $\beta$-glucuronidase liberated most of $\left[{ }^{14} \mathrm{C}\right] \mathrm{GlcA}$ as a free monosaccharide. Almost the same chromatographic profiles were observed for the transfer product formed from $\beta$ - $(1 \rightarrow 3)$-galactan. These results support the view of the transfer action of radish $\beta$-GlcATs on to acceptors that was given above.

Analysis of transfer products formed from oligosaccharide acceptors

The GlcA transfer products with oligosaccharide acceptors were produced in a large-scale reaction with prolonged incubation time $(24 \mathrm{~h})$ and isolated as ABEEderivatized compounds. Oligosaccharides subjected to $\beta$-GlcATs were $\beta$ - $(1 \rightarrow 6)$ - and $\beta$ - $(1 \rightarrow 3)$-galactotrioses, and L-Ara.Gal.Gal (Table 3). For example, a GlcA transfer product was detected by HPLC when the enzymes were incubated with L-Ara.Gal.Gal as acceptor for $4 \mathrm{~h}$ (Fig. 6). Thus, the observed efficiencies of the oligosaccharides as acceptor substrates agreed with those calculated from the radiolabel method (Table 2$)$. From $\beta$ - $(1 \rightarrow 3)$-galactotriose,

Table 3 Analyses of GlcA transfer products formed from oligosaccharides

\begin{tabular}{|c|c|c|c|}
\hline Acceptor $^{\mathrm{a}}$ & $\begin{array}{l}\text { Transfer } \\
\text { product }^{\mathrm{b}}\end{array}$ & $\begin{array}{l}\text { Elution } \\
\text { time }^{\mathrm{c}}(\min )\end{array}$ & $\begin{array}{l}\text { Transfer } \\
\text { ratio }^{\mathrm{d}}(\%)\end{array}$ \\
\hline$\beta$ - $(1 \rightarrow 6)$-galactotriose & $\mathrm{GlcA} \cdot \mathrm{Gal}_{3}$ & 35.0 & 1.8 \\
\hline \multirow[t]{2}{*}{$\beta$-(1 $\rightarrow 3)$-galactotriose } & $\mathrm{GlcA} \cdot \mathrm{Gal}_{3} \mathrm{I}$ & 31.0 & 2.2 \\
\hline & $\mathrm{GlcA} \cdot \mathrm{Gal}_{3} \mathrm{II}$ & 32.5 & 1.3 \\
\hline L-Ara·Gal·Gal & $\mathrm{GlcA} \cdot \mathrm{L}-\mathrm{Ara} \cdot \mathrm{Gal}_{2}$ & 27.5 & 4.7 \\
\hline
\end{tabular}

a The reaction was carried out at $25{ }^{\circ} \mathrm{C}$ for $4 \mathrm{~h}$ with $4 \mathrm{mM}$ of oligosaccharide

b Compositions of the GlcA transfer products were confirmed by MALDI-TOF/MS, which yielded mass values of sodium adducts $\left([\mathrm{M}+\mathrm{Na}]^{+}\right)$consistent with calculated values for either $\left[\mathrm{GlcA} \cdot \mathrm{Gal}_{3}-\right.$ $\mathrm{ABEE}+\mathrm{Na}]^{+}(\mathrm{m} / \mathrm{z}, 852.8)$ or GlcA.L-Ara. $\left.\mathrm{Gal}_{2}-\mathrm{ABEE}+\mathrm{Na}\right]^{+}(\mathrm{m} / \mathrm{z}$ 822.7)

c Elution times of each product peak on the PALPAK Type $N$ column are listed

d Transfer ratio is the percentage of GlcA transferred on to the acceptor calculated based on that of initial UDP-GlcA 


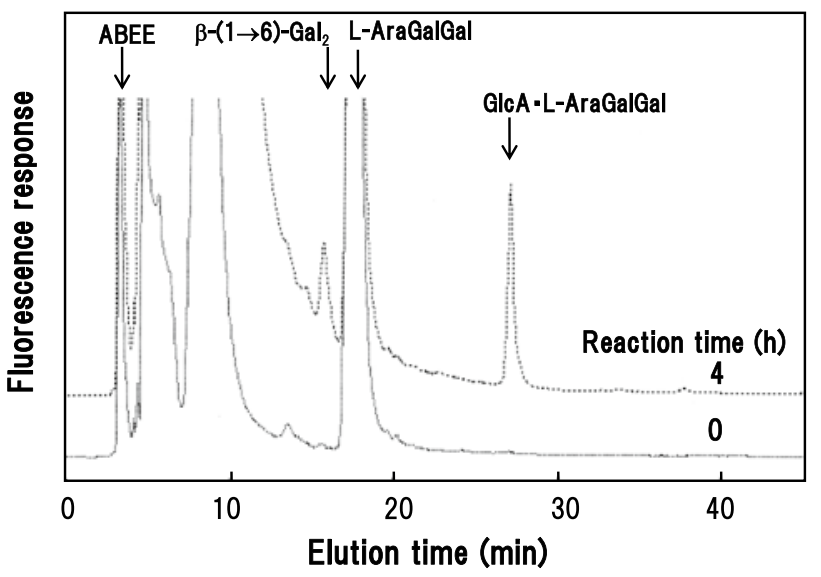

Fig. 6 Formation of a GlcA transfer product form L-Ara.Gal.Gal as the acceptor substrate. The reaction was carried out at $25^{\circ} \mathrm{C}$ for $4 \mathrm{~h}$ and products were analyzed by HPLC as ABEE derivatives. Arrows indicate the elution positions of standards and the transfer product

two products I and II, possibly regioisomers, were produced. Transfer of single GlcA residues as $\beta$-anomers into each product was confirmed by sugar composition analysis, MALDI-TOF/MS, and enzymatic hydrolysis with $\beta$-glucuronidase and $\alpha$-L-arabinofuranosidase. Digestion with the latter enzyme converted the product GlcA.LAra.Gal.Gal to GlcA.Gal.Gal, which coincided with standard $\beta$-GlcA- $(1 \rightarrow 6)-\beta$-Gal- $(1 \rightarrow 6)$-Gal by HPLC analysis, indicating the transfer of GlcA residues to either of the two Gal residues (Fig. 1).

The structure of the transfer product GlcA.LAra.Gal.Gal was analyzed by ${ }^{1} \mathrm{H}-$ and ${ }^{13} \mathrm{C}-\mathrm{NMR}$ and compared with the acceptor oligosaccharide, L-Ara.Gal.Gal (Table 4). The anomeric signals of the nonreducing terminal GlcA residues were observed at $4.46\left({ }^{1} \mathrm{H}\right)$, and $102.6 \mathrm{ppm}\left({ }^{13} \mathrm{C}\right)$. Signals due to C-6 and the methylene protons of its $\mathrm{Gal}^{\prime}$ residues in $\mathrm{L}-\mathrm{Ara} \cdot \mathrm{Gal} \cdot \mathrm{Gal}$ at $61.1 \mathrm{ppm}$ $\left({ }^{13} \mathrm{C}\right)$, and $3.74 \mathrm{ppm}\left({ }^{1} \mathrm{H}\right)$ shifted downfield to 69.1 , and 3.85 and $4.00 \mathrm{ppm}$, respectively, for the transfer product in HC-HSQC NMR spectra (Supplemental Fig. S1). These data indicate that the GlcA groups were transferred on to $\mathrm{C}-6$ of the $\mathrm{Gal}^{\prime}$ residues through $\beta$-linkages. Thus, the transfer product was identified as a branched tetrasaccharide, $\alpha$-L-Araf- $(1 \rightarrow 3)[\beta-G l c A-(1 \rightarrow 6)]-\beta$-Gal$(1 \rightarrow 6)$-Gal (Fig. 7).
Table 4 NMR data and assignment of GlcA.LAraGalGal-ABEE and L-AraGalGal-ABEE
Values underlined are characteristic signals for identification of the GlcA transfer product, GlcA $\cdot \mathrm{L}-$ AraGalGal, as ABEE derivative in comparison with the acceptor substrate, L-AraGalGal. Signals are not fully assigned due to limited amounts of the samples

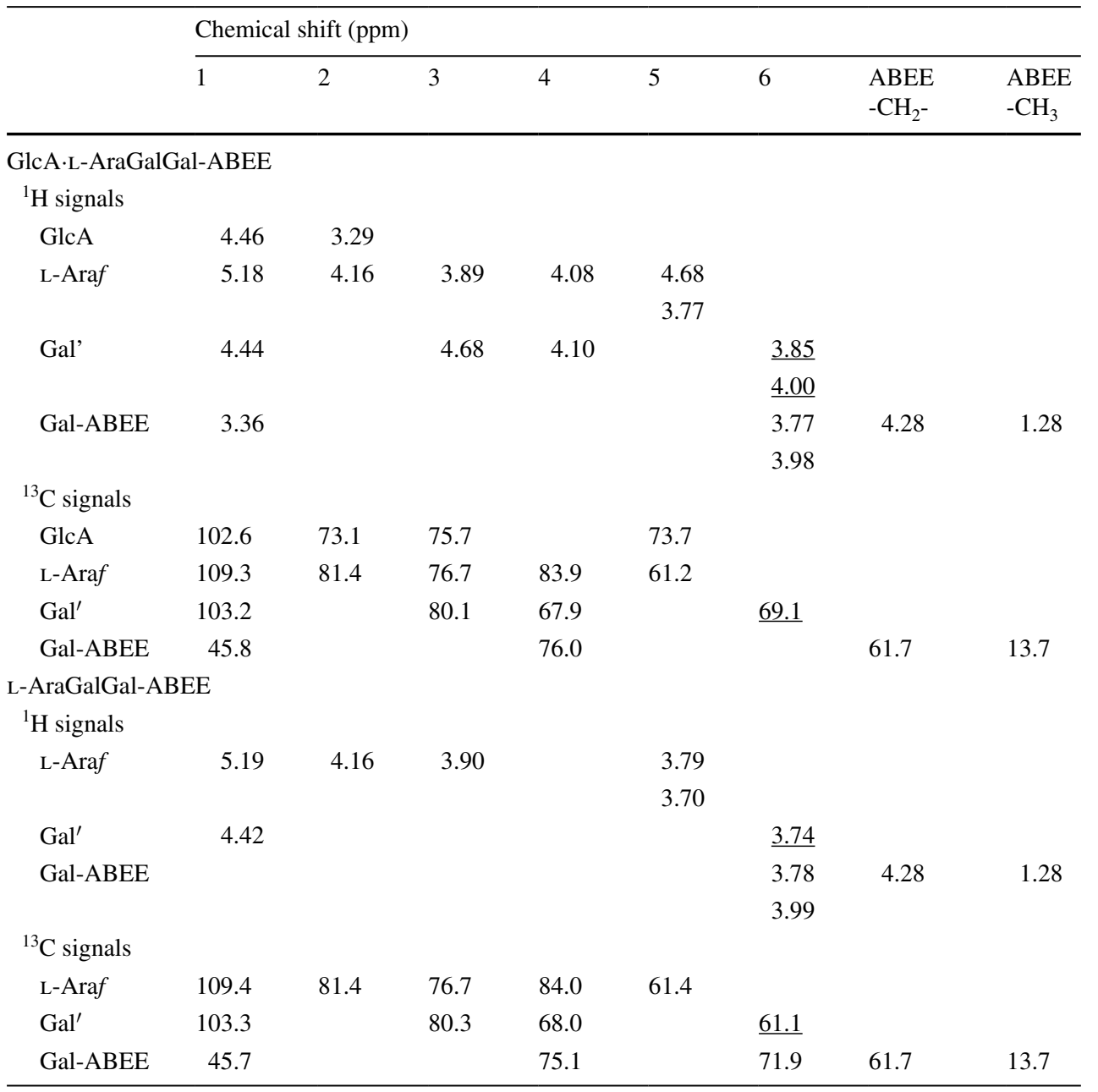




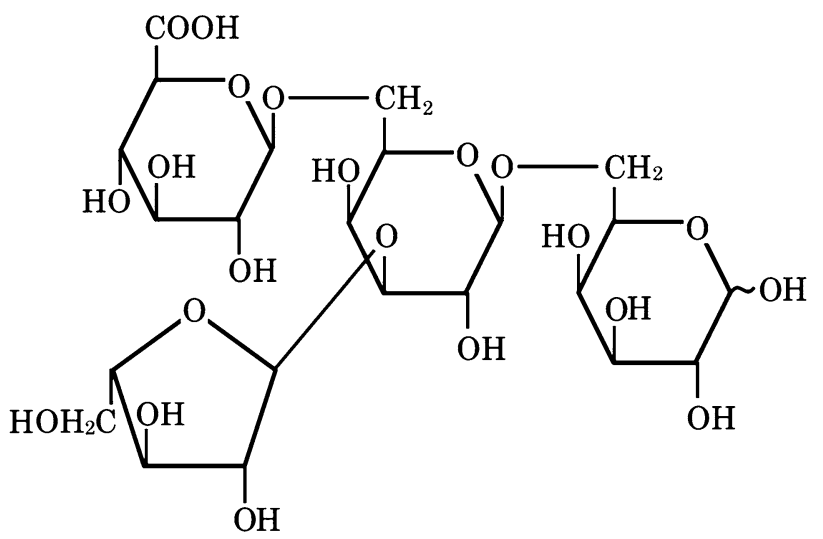

Fig. 7 The structure of the GlcA transfer product GlcA.LAra.Gal.Gal

Methylation followed by GLC analysis of the product gave terminal L-Araf and GlcA (detected as Glc on GLC) residues, and $O-3,6$-linked Gal residues, supporting the above structure. However, the peak areas of these methylated sugars did not agree well with the expected equimolar ratio, possibly due to interference from $\mathrm{ABEE}$ in the analytical process. Based on similar analyses, the transfer product formed from $\beta$ - $(1 \rightarrow 6)$-galactotriose seems to be $\beta$-GlcA- $(1 \rightarrow 6)-\beta$-Gal- $(1 \rightarrow 6)-\beta-$-Gal- $(1 \rightarrow 6)-G a l$, and the regioisomer products I and II from $\beta-(1 \rightarrow 3)$-galactotriose seem to be $\beta$-GlcA- $(1 \rightarrow 6)-\beta-$ Gal- $(1 \rightarrow 3)-\beta-G a l-$ $(1 \rightarrow 3)$-Gal and $\beta$-Gal- $(1 \rightarrow 3)[\beta$-GlcA- $(1 \rightarrow 6)]-\beta$-Gal$(1 \rightarrow 3)$-Gal. These results confirm that radish GlcATs catalyze the transfer of GlcA residues from UDP-GlcA on to acceptors preferentially through $\beta-(1 \rightarrow 6)$ linkages.

Effects of several nucleotide sugars on $\beta$-GlcAT reaction

Since we applied a membrane fraction, a crude enzyme preparation, from radish roots, it is apparent that the specimen contains many different glycosyltransferases involved in the synthesis of AG, besides $\beta$-GlcATs focused in this study. We examined the influence of several nucleotide sugars on the assay of activities of $\beta$-GlcATs using L-Ara.Gal.Gal as an acceptor substrate and several different nucleotide sugars (UDP-GlcA, -L-Ara, -Xyl, -Gal, -Glc, and GDP-Man, -Glc, and -L-Fuc) as donor substrates. The products formed by transfer of sugars were detected by HPLC as Fig. 6 (Supplemental Table S1). Coincident with our previous study, activities of GalTs and L-fucosyltransferase(s) higher than those of $\beta$-GlcATs were observed in the same radish microsomes (Misawa et al. 1996; Kato et al. 2003). Even the structures of four separated transfer products formed from UDP-Gal were not analyzed further, they might be single Gal residues attached to different positions of the acceptor substrate and/or two separate or consecutive Gal groups transferred to the substrate. These transfer products could form if oligosaccharides (see Tables 2, 3) other than L-Ara-Gal-Gal are applied as acceptor substrates. The structure of the product formed from UDP-Glc was also unclear. Therefore, our HPLC assay system is not specific in detecting $\beta$-GlcAT activities. However, most of elution times of these transfer products differed from that $(24.4 \mathrm{~min})$ for GlcA.L-Ara.Gal.Gal, indicating that GlcA transfer product was unambiguously estimated by the HPLC analysis if any small amounts of various nucleotide sugars were present in the membrane fraction. Hence, our method is valid to estimate the amounts of GlcA transfer product catalyzed by radish $\beta$-GlcATs.

\section{Discussion}

Recent studies on the synthesis of plant cell wall polysaccharides have identified many glycosyltransferase enzymes and genes, thus improving our understanding of the mechanisms and regulation of cell wall polysaccharide synthesis. Among these well characterized glycosyltransferases can be found several $\alpha$ - and $\beta$-GlcAT enzymes. For example, in the synthesis of glucuronoxylan, Mortimer et al. (2010) have identified a putative $\alpha$-GlcAT encoded by GUXI and GUX2 in Arabidopsis, which catalyzes the transfer of GlcA residues on to $\beta$ - $(1 \rightarrow 4)$-xylan chains through $\alpha-(1 \rightarrow 2)$ linkages. Zeng et al. (2010) have identified and characterized $\alpha$-GlcAT in wheat. They also demonstrated that the enzyme protein is associated with xylosyl- and L-arabinosyltransferase proteins. The enzyme complex works in a cooperative manner and regulates the synthesis of repeating oligosaccharide structures in the polysaccharide.

Although AGPs are ubiquitous in plants, not much is known about the enzymology of AG biosynthesis, and only a few enzymes, such as $\beta$-(1 $\rightarrow$ 3)-GalT (Qu et al. 2008), GalT catalyzing the synthesis of $\beta$ - $(1 \rightarrow 6)$-galactan side chains (Geshi et al. 2013), and $\alpha-\mathrm{L}-(1 \rightarrow 2)$-fucosyltransferase (Wu et al. 2010), have been identified and characterized. No $\beta$-GlcAT involved in AG synthesis has been examined for its properties or cloned. In this study, we undertook the biochemical characterization of radish GlcATs, aiming for purification of the enzyme protein and identification of the corresponding gene. A membranous $\beta$-GlcAT specimen prepared from primary roots of radish exhibited maximal activity around $\mathrm{pH} 6.0$ and required $\mathrm{Mn}^{2+}$ and Triton $\mathrm{X}-100$. These properties are similar to the $\mathrm{pH}$ range (pH 7.0) and requirement of divalent cations reported for $\alpha$-GlcAT from wheat seedlings for the synthesis of glucuronoxylan (Zeng et al. 2008). They are also similar to the requirement of divalent cations and detergent for $\alpha$-GlcAT from pea epicotyls (Waldron et al. 1989). 
Radish GlcATs catalyzed the transfer of single GlcA residues from UDP-GlcA preferentially on to $\beta$ $(1 \rightarrow 3)$-galactan and $\alpha$-L-arabinofuranosidase- and $\beta$ $(1 \rightarrow 6)$-galactanase-modified AGP through $\beta$ - $(1 \rightarrow 6)$ linkages. We conclude that the enzyme transfers GlcA residues on to both $\beta-(1 \rightarrow 3)$-galactan and $\beta$ - $(1 \rightarrow 6)$-galactosyl side chains, consistent with the proposed structure of radish and Arabidopsis AGPs, in which GlcA (and/or 4-Me-GlcA) residues are attached to $\beta$ - $(1 \rightarrow 3)$-galactan as single residue branches as well as to $\beta$ - $(1 \rightarrow 6)$-galactosyl side chains at nonreducing terminals (Tsumuraya et al. 1990; Tryfona et al. 2012). It is highly probable that the microsomes contain different $\beta$-GlcAT proteins, and we speculate that they act coordinately by transferring GlcA to $\beta-(1 \rightarrow 3)$ - and $\beta$ $(1 \rightarrow 6)$-galactan chains through $\beta-(1 \rightarrow 6)$ linkages. Essentially the same mode of action of GlcA was observed for oligosaccharide acceptors. Among oligosaccharides tested, an L-Ara-containing oligosaccharide, $\alpha$-L-Araf- $(1 \rightarrow 3)-\beta$ Gal-(1 $\rightarrow$ 6)-Gal (L-Ara·Gal-Gal), served as a much more effective acceptor than $\beta-(1 \rightarrow 6)$-galactobiose, and formed $\alpha$-L-Araf- $(1 \rightarrow 3)[\beta-$ GlcA- $(1 \rightarrow 6)]-\beta$-Gal- $(1 \rightarrow 6)-$ Gal as the transfer product. This was also observed in the case of polymer acceptors: once Smith-degraded product, carrying L-Araf residues, was a better acceptor than twice Smithdegraded product, even though the former has a lower proportion of $\beta-(1 \rightarrow 3)$-linked Gal residues (Table 1$)$. These results suggest that the L-Aarf residues facilitate the transfer of GlcA residues by the enzymes, and indicate the possibility that in vivo radish GlcATs act in a cooperative manner with L-arabinosyltransferase and other related glycosyltransferases, a scheme that has been demonstrated for GlcAT involved in the synthesis of glucuronoarabinoxylan (Zeng et al. 2010). We believe that our study contributes to the understanding of the mechanisms and regulation of the synthesis of the AG portion of AGPs.

Acknowledgments We are grateful to Dr. T. Miura, Gifu Pharmaceutical University, Gifu, Japan, and Professor T. Inazu, Tokai University, Japan for a gift of $\beta$-( $1 \rightarrow 6)$-galactopentaose.

Open Access This article is distributed under the terms of the Creative Commons Attribution License which permits any use, distribution, and reproduction in any medium, provided the original author(s) and the source are credited.

\section{References}

Albersheim P, Nevins DJ, English PD, Karr A (1967) A method for the analysis of sugars in plant cell-wall polysaccharides by gas liquid chromatography. Carbohydr Res 5:340-345

Aspinall GO, Auret BJ, Hirst EL (1958a) Gum ghatti (Indian gum). Part III. Neutral oligosaccharides found on partial acid hydrolysis of the gum. J Chem Soc: 4408-4414

Aspinall GO, Hirst EL, Ramstad E (1958b) The constitution of larch $\varepsilon$-galactan. J Chem Soc: 593-601
Basu D, Liang Y, Liu X, Himmeldirk K, Faik A, Kieliszewski M, Held M, Showalter AM (2013) Functional identification of a hydroxyproline- $O$-galactosyltransferase specific for arabinogalactan protein biosynthesis in Arabidopsis. J Biol Chem 288:10132-10143

Bradford MM (1976) A rapid and sensitive method for the quantitation of microgram quantities of protein utilizing the principle of protein-dye binding. Anal Biochem 72:248-254

Clarke AE, Anderson RL, Stone BA (1979) Form and function of arabinogalactans and arabinogalactan-proteins. Phytochemistry 18:521-540

Dubois M, Gilles KA, Hamilton JK, Rebers PA, Smith F (1956) Colorimetric method for determination of sugars and related substances. Anal Chem 28:350-356

Fincher GB, Stone BA, Clarke AE (1983) Arabinogalactan-proteins: structure, biosynthesis and function. Annu Rev Plant Physiol 34:47-70

Geshi N, Johansen JN, Dilokpimol A, Rolland A, Belcram K, Verger S, Kotake T, Tsumuraya Y, Kaneko S, Tryfona T, Dupree P, Scheller HV, Höfte H, Mouille G (2013) A galactosyltransferase acting on arabinogalactan protein glycans is essential for embryo development in Arabidopsis. Plant J. In press. doi:10.1111/tpj.12281

Gibeaut DM, Carpita NC (1991) Tracing cell wall biogenesis in intact cells and plants. Selective turnover and alteration of soluble and cell wall polysaccharides in grasses. Plant Physiol 97:551-561

Haque MA, Kotake T, Tsumuraya Y (2005) Mode of action of $\beta$-glucuronidase from Aspergillus niger on the sugar chains of arabinogalactan-protein. Biosci Biotechnol Biochem 69:2170-2177

Ishikawa M, Kuroyama H, Takeuchi Y, Tsumuraya Y (2000) Characterization of pectin methyltransferase from soybean hypocotyls. Planta 210:782-791

Kato H, Takeuchi Y, Tsumuraya Y, Hashimoto Y, Nakano H, Kováč P (2003) In vitro biosynthesis of galactans by membrane-bound galactosyltransferase from radish (Raphanus sativus L.) seedlings. Planta 217:271-282

Kitazawa K, Tryfona T, Yoshimi Y, Hayashi Y, Kawauchi S, Antonov L, Tanaka H, Takahashi T, Kaneko S, Dupree P, Tsumuraya Y, Kotake T (2013) $\beta$-Galactosyl Yariv reagent binds to the $\beta-1,3$-galactan of arabinogalactan-proteins. Plant Physiol $161: 1117-1126$

Kotake T, Dina S, Konishi T, Kaneko S, Igarashi K, Samejima M, Watanabe Y, Kimura K, Tsumuraya Y (2005) Molecular cloning of a $\beta$-galactosidase from radish that specifically hydrolyzes $\beta$ $(1 \rightarrow 3)$ - and $\beta$ - $(1 \rightarrow 6)$-galactosyl residues of arabinogalactan protein. Plant Physiol 138:1563-1576

Kotake T, Tsuchiya K, Aohara T, Konishi T, Kaneko S, Igarashi K, Samejima M, Tsumuraya Y (2006) An $\alpha$-L-arabinofuranosidase/ $\beta$ D-xylosidase from immature seeds of radish (Raphanus sativus L.). J Exp Bot 57:2353-2362

Kuroyama H, Tsutsui N, Hashimoto Y, Tsumuraya Y (2001) Purification and characterization of a $\beta$-glucuronidase from Aspergillus niger. Carbohydr Res 333:27-39

Lewis BA, Smith F, Stephen AM (1963) Metal hydride reductions. Methods Carbohydr Chem 2:68-77

Matsuura F, Imaoka A (1988) Chromatographic separation of asparagine-linked oligosaccharides labeled with an ultraviolet-absorbing compound, $p$-aminobenzoic acid ethyl ester. Glycoconjugate J 5:13-26

Misawa H, Tsumuraya Y, Kaneko Y, Hashimoto Y (1996) $\alpha$-LFucosyltransferases from radish primary roots. Plant Physiol 110:665-673

Miura T, Goto K, Waragai H, Matsumoto H, Hirose Y, Ohmae M, Ishida H, Satoh A, Inazu T (2004) Rapid oligosaccharide synthesis using a fluorous protective group. J Org Chem 69:5348-5353

Mortimer JC, Miles GP, Brown DM, Zhang Z, Segura MP, Weimar T, Yu X, Seffen KA, Stephens E, Turner SR, Dupree P (2010) 
Absence of branches from xylan in Arabidopsis gux mutants reveals potential for simplification of lignocellulosic biomass. Proc Natl Acad Sci USA 107:17409-17414

Nothnagel EA (1997) Proteoglycans and related components in plant cells. Int Rev Cytol 174:195-291

Oka T, Saito Y, Shimma Y, Yoko-o T, Nomura Y, Matsuoka K, Jigami Y (2010) Characterization of endoplasmic reticulum-localized UDP-D-galactose: hydroxyproline $O$-galactosyltransferase using synthetic peptide substrates in Arabidopsis. Plant Physiol 152: 332-340

Okemoto K, Uekita T, Tsumuraya Y, Hashimoto Y, Kasama T (2003) Purification and characterization of an endo- $\beta-(1 \rightarrow 6)$-galactanase from Trichoderma viride. Carbohydr Res 338:219-230

Qu Y, Egelund J, Gilson PR, Houghton F, Gleeson PA, Schultz CJ, Bacic A (2008) Identification of a novel group of putative Arabidopsis thaliana $\beta$-(1,3)-galactosyltransferases. Plant Mol Biol 68:43-59

Seifert GJ, Roberts K (2007) The biology of arabinogalactan proteins. Annu Rev Plant Biol 58:137-161

Sekimata M, Ogura K, Tsumuraya Y, Hashimoto Y, Yamamoto S (1989) A $\beta$-galactosidase from radish (Raphanus sativus L.) seedlings. Plant Physiol 90:567-574

Tan L, Showalter AM, Egelund J, Hernandez-Sanchez A, Doblin MS, Bacic A (2012) Arabinogalactan-proteins and the research challenges for these enigmatic plant cell surface proteoglycans. Front Plant Sci 3:140

Tryfona T, Liang HC, Kotake T, Tsumuraya Y, Stephens E, Dupree P (2012) Structural characterization of Arabidopsis leaf arabinogalactan polysaccharides. Plant Physiol 160:653-666
Tsumuraya Y, Hashimoto Y, Yamamoto S, Shibuya N (1984) Structure of L-arabino-D-galactan-containing glycoproteins from radish leaves. Carbohydr Res 134:215-228

Tsumuraya Y, Ogura K, Hashimoto Y, Mukoyama H, Yamamoto S (1988) Arabinogalactan-proteins from primary and mature roots of radish (Raphanus sativus L.). Plant Physiol 86:155-160

Tsumuraya Y, Mochizuki N, Hashimoto Y, Kováč P (1990) Purification of an exo- $\beta$ - $(1 \rightarrow 3)$-D-galactanase of Irpex lacteus (Polyporus tulipiferae) and its action on arabinogalactan-proteins. J Biol Chem 265:7207-7215

Uesaka E, Sato M, Raiju M, Kaji A (1978) $\alpha$-L-Arabinofuranosidase from Rhodotorula flava. J Bacteriol 133:1073-1077

Waldron KW, Baydoun EAH, Brett CT (1989) The solubilization of a glucuronyltranferase involved in pea (Pisum sativum var. Alaska) glucuronoxylan synthesis. Biochem J 264:643-649

Wu Y, Williams M, Bernard S, Driouich A, Showalter AM, Faik A (2010) Functional identification of two nonredundant Arabidopsis $\alpha-(1,2)$ fucosyltransferases specific to arabinogalactan proteins. J Biol Chem 285:13638-13645

Zeng W, Chatterjee M, Faik A (2008) UDP-xylose-stimulated glucuronyltransferase activity in wheat microsomal membranes: characterization and role in glucurono(arabino)xylan biosynthesis. Plant Physiol 147:78-91

Zeng W, Jiang N, Nadella R, Killen TL, Nadella V, Faik A (2010) A glucurono(arabino)xylan synthase complex from wheat contains members of the GT43, GT47, and GT75 families and functions cooperatively. Plant Physiol 154:78-97 